\title{
MENAKAR REPRESENTASI DPRD SEBAGAI PERAN DAKWAH [Studi Kasus di DPRD Kabupaten Ponorogo Jawa Timur]
}

\author{
Nur Kholis dan Luthfi Ulfa Ni'amah \\ Fakultas Dakwah IAIN Tulungagung \\ e-mail: fakhryaqil@gmail.com dan \\ e-mail: luthfie_un@yahoo.co.id
}

\begin{abstract}
This research studied the understanding of legislative members for their function in spreading The religious values of Pancasila at Regional House of Representatives Ponorogo, East Java. By conducting qualitative method, the writer analyzes the implementation of the function and the role of the legislative member as a medium of propaganda, both of chairman of parliament and the members. The data were collected in-depth interview, documentation, and observation. In determining of the data, the writer uses the inspection techniques; credibility, transferability, and dependability for confirming its validity. Then, the data have been analyzed in phases and interconnected between data reduction, data presentation, conclusion, and verification. The study concluded that the legislators understand their function is parallel to their religious values in amar ma'ruf nahi munkar for realizing the values of Pancasila, the aims of democracy, in order to achieve prosperous society, mutual cooperation, mutual respect and managing the diversity of religion, race, and ethnicity in the frame of Bhineka Tunggal Ika.
\end{abstract}

\section{Key Word:}

Role, Implementation, Refresentatives, Da'wah 


\begin{abstract}
Abstrak
Penelitian ini mempelajari pemahaman anggota legislatif atas fungsinya dalam menyebarkan nilainilai agama Pancasila di Dewan Perwakilan Rakyat Daerah Ponorogo, Jawa Timur. Dengan melakukan metode kualitatif, penulis menganalisis pelaksanaan fungsi dan peran anggota legislatif sebagai media propaganda, baik ketua parlemen maupun anggota. Data dikumpulkan dengan wawancara mendalam, dokumentasi, dan observasi. Dalam menentukan data, penulis menggunakan teknik pemeriksaan; Kredibilitas, kemampuan transfer, dan ketergantungan untuk mengkonfirmasikan keabsahannya. Kemudian data dianalisis secara bertahap dan saling keterkaitan antara reduksi data, penyajian data, kesimpulan, dan verifikasi. Studi tersebut menyimpulkan bahwa para legislator memahami fungsinya sejajar dengan nilainilai agama mereka di amar ma'ruf nahi munkar karena mewujudkan nilai-nilai Pancasila, tujuan demokrasi, dalam rangka mewujudkan masyarakat sejahtera, gotong royong, saling menghormati dan mengelola keanekaragaman. Agama, ras, dan etnis dalam bingkai Bhineka Tunggal Ika.
\end{abstract}

\title{
Kata Kunci:
}

Peran, Implementasi, Representasi, Dakwah 


\section{A. Pendahuluan}

Kedudukan sebagai wakil rakyat memiliki makna penting dalam proses perubahan masyarakat, umat, dan bangsa. Dalam konteks agama Islam hal ini dapat diartikan sebagai proses dakwah, amar ma'ruf nahyi munkar. Tujuan dakwah adalah terjadinya perubahan pola pikir, pola sikap, dan pola perilaku masyarakat. Perubahan ini dapat dilakukan secara mandiri oleh komunitas masyarakat maupun atas dorongan/fasilitas dari pihak-pihak luar komunitas. Dorongan dari pihak luar dapat dilakukan dengan pendekatan kultural dan struktural. Dakwah yang dilakukan oleh para anggota dewan perwakilan melalui implementasi peran dan fungsinya di lembaga legislatif merupakan bagian dari dakwah struktural. Proses keterwakilan dalam konteks politik sesungguhnya dapat menyangkut dua hal, yakni; keterwakilan dari sisi kepentingan dan keterwakilan dari sisi opini.

Penelitian ini bertujuan untuk mengetahui, dan mendeskripsikan pemahaman anggota dewan dalam pelaksanaan peran dan fungsinya di lembaga legislatif sebagai dakwah dalam kerangka perubahan masyarakat lebih sejahtera lahir batin. Kebanyakan penelitianpenelitiansebelumnya lebih menjelaskan implementasi peran dan fungsi anggota DPRD untuk pengawasan keuangan, sebagaimana penelitian yang dilakukan oleh Isma, ${ }^{62}$ Werimon, dkk, ${ }^{63}$ Dewi, ${ }^{64}$ Kartikasari, ${ }^{65}$ dan Darma; ${ }^{66}$ dan masih sedikit yang meneliti peran dakwah anggota

${ }^{62}$ C. Isma, Akuntabilitas, Partisipasi Masyrakat, dan Transparansi Kebijakan Publik sebagai Pemoderating Hubungan Pengetahuan Dewan tentang Anggaran dan Pengawasan Keuangan Daerah (APBD). 12 (2), 121-137.

${ }^{63}$ S. Werimon, I. Ghozali, \& M. Nazir, "Pengaruh Partisipasi Masyarakat dan Transparansi Kebijakan Publik terhadap Hubungan Antara Pengetahuan Dewan Tentang Anggaran dengan Pengawasan Keuangan dDaerah (APBD)", (Study Empiris di Provinsi Papua), 2007.

${ }^{64}$ I. M. Dewi, Analisis Faktor-faktor yang Mempengaruhi Kapabilitas Anggota DPRD dalam Pengawasan Keuangan Daerah (APBD), Disertasi (Semarang: Universitas Diponegoro, 2011 ).

${ }^{65}$ D. Kartikasari, Pengaruh Personal Background, Political Background, Pemahaman Regulasi Terhadap Peran anggota DPRD dalam Pengawasan Keuangan Daerah (Studi Kasus pada DPRD Kabupaten Boyolali). Dalam Accounting Analysis Journal, 1 (2012), 12-19.

${ }^{66} \mathrm{~J}$. Darma, \& A. F. Hasibuan, "Pengaruh Pengetahuan Anggota Dewan tentang Anggaran Terhadap Pengawasan Keuangan Daerah dengan Partisipasi Masyarakat sebagai 
dewan sebagaimana penelitiannya Zamany, ${ }^{67}$ Siregar. ${ }^{68}$ Penelitian ini diharapkan memberikan gambaran kepada khalayak bahwa terdapat peran kenabian dalam implementasi peran, fungsi, dan wewenang anggota parlemen. Mereka tidak hanya melaksanakan fungsi formal kenegaraan semata, tetapi juga peran-peran dakwah yang didasarkan pada nilai-nilai, norma, dan etika keagamaan dan Pancasila.

\section{B. Metode Penelitian}

Jenis penelitian ini adalah kualitatif menggunakan pendekatan studi kasus. Penelitian dilakukan di DPRD Kabupaten Ponorogo, Jawa Timur. Objek penelitian adalah implementasi fungsi dan peran DPRD sebagai media dakwah, sedangkan subjeknya adalah anggota legislatif dan pimpinan DPRD Kabupaten Ponorogo, Jawa Timur. Datadata dikumpulkan melalui teknik wawancara mendalam, dokumentasi dan observasi. Untuk mengukur keabsahan data digunakan teknik pemeriksaan; credibility, transferability, dependability, dan confirmability. Analisis data dilakukan secara berjenjang dan saling terkait antara reduksi data, penyajian data, penarikan kesimpulan dan verifikasi.

\section{Representasi Peran Dakwah Wakil Rakyat}

Setiap individu dengan memaksimalkan panca indranya dapat merepresentasikan dunia luarnya dalam aktifitas kesehariannya. Semua hal yang terlihat, terdengar, teraba, terasa, tercium dapat dimaknai dan direkonstruksi kembali dalam wujud pemikiran, sikap, dan perilaku. Sebagian ahli mengungkapkan bahwa representasi hakikatnya adalah merekonstruksi dunia luarnya, "representasi lebih dilihat sebagai suatu proses mengkonstruksi dunia sekitar kita dan juga proses memaknainya." ${ }^{\circ 9}$ Wujud representasi adalah penggunaan

Variabel Moderating", dalam Jurnal Mediasi, 4 (2012), 49-58.

${ }^{67}$ R. P. A. F. Zamany, Dakwah Politik: Telaah Aktivitas Dakwah Politik Anggota DPRD Jawa Timur Periode 2014-2019, Disertasi (Surabaya: UIN Sunan Ampel Surabaya, 2015).

${ }^{68}$ W. Z. B. Siregar, "Periuangan dan Peran Perempuan di DPRD Jawa Timur, dalam Sumber, 11, 16.

${ }^{69}$ P. Manurung, "Membaca Representasi Tubuh dan Identitas sebagai Sebuah Tatanan Simbolik dalam Majalah Remaja", dalam Jurnal Ilmu Komunikasi, 1 (1: 2013), 37-72. 
bahasauntukmenyatakan sesuatu secarabermakna, merepresentasikan diri pada orang atau komunitas masyarakat tertentu. Dalam hubungan antar individu dengan individu atau kelompok lainnya, representasi merupakan bagian penting dalam proses di mana bahasa diproduksi dan dipertukarkan diantara simbol-simbol yang ada. Representasi melibatkan penggunaan bahasa dalam tanda-tanda (sign-sign) dan image-image yang mewakili atau mempresentasikan sesuatu. ${ }^{70}$ Bahasa, dalam konteks pergaulan, komunikasi, dan keterjalin hubungan antara individu satu dengan lainnya dapat dimaknai sebagai representasi dari objek. Representasi adalah kegiatan membuat realitas namun bukan realitas yang sesungguhnya, mengunakan bahasa dan imaji untuk menciptakan makna tentang dunia sekitar. Penggunaan bahasa untuk memahami, menggambarkan dan menjelaskan dunia. Proses ini terjadi melalui sistem representasi, seperti media bahasa dan visual, yang memiliki aturan dan konvensi tentang bagaimana mereka diorganisir. ${ }^{71}$

Representasi bagi kebanyakan para anggota dewan dimaknai sebagai perbuatan mewakili, keadaan yang diwakili, apa yang diwakili, dan perwakilan. Baginya, menjadi wakil rakyat adalah mewakili keseluruhan aspirasi masyarakat, mewakili situasi, dan kondisi masyarakat daerah pilihannya. Ruang lingkup representasinya meliputi keseluruhan aspirasi masyarakat dalam segala aspeknya; ekonomi, politik, pendidikan, budaya, keagamaan, dan seni. Aspirasi masyarakat meliputi; keinginan, harapan, tujuan, cita-cita, perasaan, dan emosi yang wajib menjadi inhern dalam keseluruhan pola pikir, pola sikap, dan pola perilaku keseharian para wakil rakyat. Dalam mengimplementasikan keluasan ruang lingkup representasi itu maka dibentuklah struktur kepemimpinan lembaga perwakilan menjadi beberapa bidang kerja sesuai dengan besaran dan luasan dinas/kantor dalam lembaga eksekutif. Pada masing-masing komisi ini, mereka

${ }^{70}$ R. W. Winarni "Representasi Kecantikan Perempuan dalam Iklan", dalam Deiksis, 2(02: 2015), 134-152.

${ }^{71} \mathrm{M}$. Sturken And Lisa Cartwright, Practices of Looking, an Introduction to Visual Culture (New York: Oxford University Press, 2001). 
menginisiasi Peraturan Daerah (perda), mendorong pelaksanaan perda, dan mengontrol pelaksanaan. Perda-perda yang diproduksi bersama dengan pihak eksekutif dimaksudkan untuk memberikan pelayanan kepada masyarakat yang mengacu kepada visi, misi, program dan kegiatan pemerintah daerah. Perda dibuat dalam rangka sebagai payung hukum implementasikan program dan kegiatan, baik yang sifatnya jangka panjang lima tahunan, menengah, maupun jangka pendek.

Pengetahuan dan pemahaman tentang tugas, wewenang, danfungsi anggota dewan di Kabupaten Ponorogo menurut mereka diperoleh dari beberapa kegiatan, diantaranya; keterlibatan sebelumnya dalam partai politik masing-masing, diskusi dengan teman sejawat, membaca teori-teori yang terkait dengan kemasyarakatan, diskusi formal, sidang komisi, sidang/rapat pleno, rapat partai, dan kunjungan ke konstituen dalam momentum jaring aspirasi masyarakat (jasmas). Selain itu, menurut pemahaman mereka bahwa menjadi anggota legislatif merupakan proses belajar dan dakwah untuk mengetahui dan memahami masyarakat/konstituen. Proses ini tidak mengenal batas akhir, karena menjadi anggota legislatif hakikatnya adalah belajar menjadi bagian dari masyarakat dan berdakwah dalam bentuk menyalurkan aspirasi masyarakat, menginisiasi kebaikan untuk semua masyarakat (amar ma'ruf nahyi mungkar).

Nilai-nilai, harapan, keinginan, tujuan, dan rasa penyatuan diri dengan konstituen merupakan hal yang selalu diperjuangkan dalam dakwah sebagai manifestasi pelaksanaan tugas dan fungsinya. Sebagian besar dari mereka menyadari bahwa kehadiran dirinya ditengah kehidupan masyarakat atau konstituennya tidak semata hubungan formal politik tetapi juga dihayati sebagai sosialisasi diri dan instrument bagi proses perjuangan untuk masyarakatnya, hal demikian relevan dengan kajian Amalia $^{72}$. Tuntutan masyarakat merupakan tujuan dari kehadirannya, keinginan masyarakat

${ }^{72}$ N. F. Amalia, "Faktor-faktor yang Mempengaruhi Peran DPRD dalam Pengawasan Keuangan Daerah", dalam Accounting Analysis Journal, 2 (2013). 
merupakan proses perjuangannya, emosinya merupakan bagian dari nafas masyarakatnya sehingga kehadiarannya memiliki fungsi dakwah dalam konteks amar ma'ruf, sebagaimana penelitian yang dilakukan oleh Lombo; ${ }^{73}$ dan Tardjono..$^{74}$ Penghayatan terhadap semua bentuk aspirasi masyarakat dipelajari melalui bacaan teori-teori dari beragam buku, direfleksikan melalui diskusi formal dan nonformal lembaga politik kenegaraan, dicari dan ditemukan solusi melalui jalan negosiasi dengan lembaga eksekutif untuk mencapai keadilan dan kesejahteraan masyarakat. Karena itu, optimalisasi pengawasan terhadap eksekutif dan memproduksi peraturan daerah sesuai dengan aspirasi masyarakat menjadi suatu keniscayaan, analisa demikian mendukung hasil penelitian yang dilakukan oleh Santoso; ${ }^{75}$ dan Faizal ${ }^{76}$. Inilah yang diidealkan oleh Demokrasi Pancasila yang menjadi ciri utama politik di Indonesia, demokrasi yang menghargai keragaman dalam berpendapat, pilihan, dan cara pandang terhadap suatu fenomena dengan mengedepankan persatuan dan kesatuan bangsa.

Partai politik dan lembaga perwakilan daerah memiliki peran penting dalam merumuskan, mengawal, dan mengontrol sistem politik agar tetap berada pada jalur untuk mewujudkan demokrasi Pancasila. DemokrasiPancasilaadalah demokrasiyang berdasarkankekelvargaan dan gotong-royong yang ditujukan kepada tercapainya kesejahteraan rakyat, mengandung unsur-unsur berkesadaran religius, berdasarkan kebenaran, kecintaan dan budi pekerti luhur, berkepribadian Indonesia dan berkesinambungan ${ }^{77}$. Dalam demokrasi Pancasila kebebasan

${ }^{73}$ M. R. Lombo, "Fungsi Dewan Perwakilan Rakyat dalam Penyelenggaraan Pemerintahan Setelah Amandemen UUD 1945", dalam Lex Et Societatis, 4(2.1), 2016, 47-54.

${ }^{74}$ Tardjono, "Degradasi Kewenangan Legislasi Badan Legislasi DPR RI Pasca Revisi UU No. 27 Tahun 2009 tentang MPR, DPR, DPD, dan DPRD", dalam Jurnal Renaissance, 1 (01), 2016, 11-16.

${ }^{75}$ Santoso, "Peran Dewan Perwakilan Rakyat Daerah dalam Menjalankan Fungsi Pengawasan", dalam Jurnal Hukum lus Quia lustum, 18 (4: 2016), 604-620.

${ }^{76} \mathrm{~L}$. Faizal, "Fungsi Pengawasan DPRD di Era Otonomi Daerah", dalam Jurnal Tapis, 7 (2:2011).

${ }^{77}$ Mohammad Hatta, "Indonesia Merdeka", dalam karya lengkap Bung Hatta. Buku I: Kebangsaan dan Kerakyatan (Jakarta: Penerbit LP3ES, 1998), 87. 
individu tidak bersifat mutlak, tetapi harus diselaraskan dengan tanggung jawab sosial78, hal ini sesuai dengan prinsip dasar dalam berdakwah bahwa amar ma'ruf nahyi munkar merupakan bagian dari tanggung jawab sosial manusia pada umumnya terhadap keluarga, kelompok masyarakat (komunitas), bangsa dan negara. Tanggung jawab demikian merupakan tanggungjawab universal, tidak hanya terbatas pada ras, suku, bahasa, dan agama tertentu, karena dalam konteks Indonesia masyarakatnya sangat beragam. Dalam demokrasi Pancasila, universalitas cita-cita demokrasi dipadukan dengan cita-cita hidup bangsa Indonesia yang dijiwai oleh semangat kekelvargaan, sehingga tidak ada dominasi mayoritas atau minoritas..$^{79}$

DemokrasiPancasilaadalah normayang mengaturpenyelenggaraan kedaulatan rakyat dan penyelenggaraan pemerintahan negara, dalam kehidupan politik, ekonomi, sosial budaya, dan pertahanan keamanan bagi setiap warga negara Republik Indonesia, organisasi sosial politik, organisasi kemasyarakatan, dan lembaga-lembaga kemasyarakatan lainnya serta lembaga-lembaga Negara baik di Pusat, Propinsi maupun di Daerah. Kepentingan berpolitik tidak hanya semata untuk mencapai tujuan pribadi individu, partai politik, atau kelompok tertentu, tetapi semua orientasi politik ditujukan untuk mensejahterakan rakyat, inilah hakikat dakwah dalam komunitas parlemen baik di Pusat, Propinsi, maupun di Kabupaten/Kota. Kesejahteraan rakyat hendaknya menjadi tujuan bersama partai-partai yang ada, tetapi paradigma, cara pandang dan cara kerja, serta jalinan kemitraan yang dibangun bisa jadi berbeda-beda sesuai dengan platform masing-masing partai. Ideology dan platform partai boleh berbeda bahkan cara atau teknik pencapaian tujuan mensejahterakan rakyat bisa jadi juga berbeda tetapi semangat dalam mengembangkan model pencapaian tujuan kesejahteraan rakyat harus sama. Kepentingan kelompok dan/atau pribadi masing-masing partai atau insan politik boleh berbeda tetapi

${ }^{78}$ Yudi Latif, Negara Paripurna, Historisitas, Rasionalitas dan Aktualitas Pancasila, (Jakarta: Gramedia, 2011 1), 383.

${ }^{79} \mathrm{lbid}, 250$. 
tujuan bersama merupakan suatu keniscayaan. Oleh karena itu, diperlukan prinsip-prinsip yang mendasari pelaksanaan demokrasi Pancasila sehingga semua angota atau stakeholders politik mengetahui, memahami, dan bersedia mengimplementasikannya dalam kehidupan keseharian bermasyarakat, berbangsa, dan bernegara.

Pelaksanaan demokrasi Pancasila dalam pemerintahan meniscayakan prinsip-prinsip dasar yang meliputi; kebebasan atau persamaan (freedom/equality), kedaulatan rakyat (people's sovereignty), dan pemerintahan yang terbuka bertanggung jawab ${ }^{80}$. Kebebasan atau persamaan adalah dasar demokrasi. Kebebasan dimaknai sebagai suatu sarana untuk mencapai kemajuan dan memberikan hasil maksimal dari usaha orang-orang atau kelompok tanpa pembatasan dari penguasa. Prinsip persamaan berpandangan bahwa semua orang dianggap sama, tanpa dibeda-bedakan, dan memperoleh akses dan kesempatan bersama untuk mengembangkan diri sesuai dengan bakat dan potensi yang dimilikinya. Kebebasan yang dikandung dalam demokrasi Pancasila ini tidak berarti free fight liberalism sebagaimana tumbuh di Negara-Negara Barat, tapi kebebasan yang tidak mengganggu hak dan kebebasan orang lain. Kebebasan yang terbatas, karena hakikat dari kebebasan itu adalah terbatas pada kebebasannya itu sendiri dan tanggung jawab sosial. Misalnya, setiap orang bebas memilih partai politik tertentu untuk dipilihnya, maka kebebasannya hanya terbatas untuk memilih partai tersebut. Memilih partai yang didasarkan atas kesadaran mewujudkan kesejahteraan bersama, maka pilihan demikian merupakan manifestasi atau wujud dari tanggung jawab sosialnya. Dengan demikian partai politik, anggota legislatif yang terpilih hakikatnya merupakan representasi rakyat yang harus dapat mewujudkan keinginan dan aspirasi politik masyarakat atau konstituennya.

Kedaulatan rakyat (people's Sovereignty) mengandung makna bahwa hakikat kebijakan yang dibuat adalah kehendak rakyat dan

${ }^{80} \mathrm{Jimly}$ Asshiddiqie, Hukum Tata Negara \& Pilar-pilar Demokrasi (Jakarta: Sinar Grafika, $2011), 198-234$. 
untuk kepentingan rakyat. Mekanisme semacam ini akan mencapai dua hal, yaitu; Pertama, kecil kemungkinan terjadinya penyalahgunaan kekuasaan. Pemerintahakanmenghadirkan semuakebijakan, program, dan kegiatan-kegiatan yang menjamin terselenggaranya pencapaian kesejahteraan semua rakyat. Kedua, terjaminnya kepentingan rakyat dalam tugas-tugas pemerintahan. Pemerintah memiliki kewenangan, peran, dan tugas untuk menghadirkan diri dan fungsinya dalam menjamin tercapainya kesejahteraan rakyat, karenanya program sejatinya adalah merupakan pengejawantahan dari proses untuk menjamin kepentingan rakyat. Perwujudan lain dari konsep kedaulatan rakyat adalah pengawas oleh rakyat. Pengawasan dilakukan karena demokrasi tidak mempercayai kebaikan hati penguasa, yaituang berfungsi mengawasi ini adalah para wakil rakyat, baik di Pusat, Propinsi, dan Kabupaten/Kota. Fungsi pengawasan adalah merupakan fungsi nahyi munkar dalam konteks berdakwah. Dalam semua lapisan masyarakat, akan menjadi elok jika ada komunitas-komunitas yang memiliki peran pengontrol terhadap pemikiran, sikap, dan perilakukebijakan pemerintah.

\section{Kesimpulan}

Setiap anggota legislatif merupakan representasi dari konstituennya yang mencakup; keinginan, cita-cita, harapan, dan emosi dalam ruang lingkup semua aspek kehidupan manusia, yaitu; pendidikan, ekonomi, sosial, keagamaan, seni, dan budaya. Untuk mendukung terlaksananya representasi demikian diperlukan fungsi dan peran masing-masing anggota legislatif, yang meliputi; fungsi anggaran, pengawasan, dan legislasi. Optimalisasi fungsi dan perannya dimaknai sebagai peran dakwah untuk merealisasikan cita-cita demokrasi Pancasila dalam mewujudkan masyarakat sejahtera lahir batin, gotong royong, saling mengharagai dan menghormati keragaman dalam agama, ras, suku, dan bahasa dalam bingkai bhineka tungga ika sebagai wujud amar ma'ruf nahi munkar yang merupakan cita-cita dan tujuan dakwah. 


\section{Daftar Pustaka}

Amalia, N. F., "Faktor-Faktor yang Mempengaruhi Peran DPRD dalam Pengawasan Keuangan Daerah", dalam Accounting Analysis Journal, 2013: 2(3)

Asshiddiqie, Jimly, Hukum Tata Negara \& Pilar-Pilar Demokrasi (Jakarta: Sinar Grafika, 2011)

Darma, J., \& Hasibuan, A. F., Pengaruh pengetahuan anggota dewan tentang anggaran terhadap pengawasan kevangan daerah dengan partisipasi masyarakat sebagai variabel moderating. Jurnal Mediasi, 2012: 4 (01)

Dewi, I. M., "Analisis Faktor-Faktor yang Mempengaruhi Kapabilitas Anggota DPRD dalam Pengawasan Keuangan Daerah (APBD)", dalam Disertasi (Semarang: Universitas Diponegoro, 2011)

Faizal, L., "Fungsi Pengawasan DPRD di Era Otonomi Daerah", dalam Jurnal Tapis, $2011: 7(2)$

Hatta, Mohammad, "Indonesia Merdeka" dalam Bung Hatta, Kebangsaan dan Kerakyatan (Jakarta: Penerbit LP3ES, 1998)

Isma, C., Akuntabilitas, Partisipasi Masyarakat, dan Transparansi Kebijakan Publik sebagai Pemoderating Hubungan Pengetahuan Dewan tentang Anggaran dan Pengawasan Keuangan Daerah (APBD), 2014: 12(2)

Kartikasari, D., "Pengaruh Personal Background, Political Background, Pemahaman Regulasi terhadap Peran Anggota DPRD dalam Pengawasan Keuangan Daerah (studi kasus pada DPRD Kabupaten Boyolali)", dalam Accounting Analysis Journal, 2012: 1 (1)

Latif, Yudi, Negara Paripurna, Historisitas, Rasionalitas dan Aktualitas Pancasila (Jakarta: Gramedia, 2011)

Lombo, M. R., "Fungsi Dewan Perwakilan Rakyat dalam Penyelenggaraan Pemerintahan Setelah Amandemen UUD 1945", dalam Lex Et Societatis, 2016: 4(2.1) 
Manurung, P. H., "Membaca Representasi Tubuh dan Identitas sebagai sebuah Tatanan Simbolik dalam Majalah Remaja", dalam Jurnal Ilmu Komunikasi, 2013: 1(1)

Santoso, "Peran Dewan Perwakilan Rakyat Daerah dalam Menjalankan Fungsi Pengawasan", dalam Jurnal Hukum lus Quia lustum, 2011 : 18 (4)

Sturken, M. And Lisa Cartwright, Practices of Looking, an Introduction to Visual Culture (New York: Oxford University Press, 2001)

Tardjono, H., "Degradasi Kewenangan Legislasi Badan Legislasi DPR RI Pasca Revisi UU No 27 Tahun 2009 Tentang MPR, DPR, DPD, dan DPRD", dalam Jurnal Renaissance, 2016: 1 (01)

Werimon, S., Ghozali, I., \& Nazir, M., "Pengaruh Partisipasi Masyarakat dan Transparansi Kebijakan Publik terhadap Hubungan antara Pengetahuan Dewan tentang Anggaran dengan Pengawasan Keuangan Daerah (APBD) (Study empiris di Provinsi Papua)", dalam Laporan Hasil Penelitian (2007)

Winarni, R. W., "Representasi Kecantikan Perempuan dalam Iklan", dalam Jurnal Deiksis, 2015: 2 (02)

Zamany, R. P. A. F., "Dakwah Politik: Telaah Aktivitas Dakwah Politik Anggota DPRD Jawa Timur Periode 2014-2019", dalam Disertasi (Surabaya: UIN Sunan Ampel, 2015) 